\title{
A NEW SPECIES OF RHINORCHIS (ORCHIDACEAE, HABENARIINAE) FROM FRENCH GUIANA
}

\author{
Dariusz L. SzlachetKo \& Marta Kolanowska ${ }^{1}$
}

\begin{abstract}
Rhinorchis heteroplectron Rchb. f. ex Szlach. \& Kolan., a new species from French Guiana, is described and illustrated. The differences between $R$. heteroplectron and similar species are briefly discussed and an identification key for representatives of the genus reported from French Guiana is included.
\end{abstract}

Key words: biodiversity, Habenaria, Neotropics, taxonomy

Dariusz L. Szlachetko \& Marta Kolanowska, Department of Plant Taxonomy and Nature Conservation, University of Gdańsk, Wita Stwosza 59,80-308 Gdańsk, Poland; e-mail: martakolanowska@wp.pl

\section{INTRODUCTION}

The cosmopolitan subtribe Habenariinae is the largest taxon of this rank in Orchideae (Orchidaceae). Due to the high morphological variability observed in its taxa, generic delimitation within those orchids is problematic. Over 1800 specific names have been applied to Habenaria Willd., the type genus of this subtribe which is widely distributed in the tropical and subtropical zones. The need to split Habenaria into smaller, morphologically clearly defined genera is a topic of ongoing discussion among orchidologists. The first attempt to divide Habenaria was made by Rafinesque (1837) but his findings were not widely accepted. Modern studies on the gynostemium structure of Habenariinae resulted in separation of three new genera from the Neotropical representatives of Habenaria - Bertauxia Szlach. (Szlachetko 2004a), Kusibabella Szlach. (Szlachetko 2004b) and Rhinorchis Szlach. (Szlachetko 2012) - and restitution of Habenella Small (Szlachetko \& Kras 2006). While the latter genus contains species known from tropical Asia, Africa and the New World, the three newly described genera are limited in their distribution to South and Central America.

\footnotetext{
1 Corresponding author
}

All those plants are characterized by dissimilar tepals with a cucullate dorsal sepal hiding the gynostemium, which is characterized by elongate antherophores, stigmaphores and rostellophores (Szlachetko 1995).

As currently recognized, the Neotropical representatives of Habenariinae may be identified based on their floral characters. Entire lips and petals are observed only in Habenella (Szlachetko \& Kras 2006); in all other genera those perianth segments are deeply lobed. An elongate rostellum middle lobe is produced exclusively by plants of Rhinorchis (Szlachetko 2012), and only in Bertauxia does the rostellum form a platform between the thecae and stigma lobes (Szlachetko 2004a). The main difference between Habenaria and Kusibabella lies in the form and size of the stigmaphores (Szlachetko 2004b).

During our recent revision of the Neotropical Habenariinae we found a distinctive specimen of Rhinorchis from French Guiana in Reichenbach's orchid collection in Vienna. The herbarium sheet was labeled 'Habenaria heteroplectron' but such a name has never been effectively published (Art. 29.1 ICN, McNeill et al. 2012). It is here validated as a Rhinorchis species and placed within a key to identification of national representatives of the genus. 


\section{DESCRIPTION OF THE NEW SPECIES}

Rhinorchis heteroplectron Rchb. f. ex Szlach. \& Kolan., sp. nov.

Fig. 1

Species similar to Rhinorchis macilenta (Lindley) Szlach. but distinguished by the short anterior petal lobe and filiform, acute spur.

HoLOTYPE: FRENCH GUIANA. Leprieur s.n. (W).

Plants ca $27 \mathrm{~cm}$ tall, slender, delicate, erect. Leaves 5-6, cauline, up to $7 \mathrm{~cm}$ long, $0.3-0.4 \mathrm{~cm}$ wide, linear-lanceolate, acute, erect, adpressed to stem. Inflorescence 2-flowered. Flowers rather small, resupinate. Floral bracts $15-25 \mathrm{~mm}$ long, linear-lanceolate. Pedicel 20-30 mm long. Ovary $15 \mathrm{~mm}$ long. Dorsal sepal ca $9 \mathrm{~mm}$ long, $5 \mathrm{~mm}$ wide, oblong ovate to ovate-lanceolate, obtuse, shortly apiculate. Petals bipartite almost to base; anterior lobe $5 \mathrm{~mm}$ long, $0.8 \mathrm{~mm}$ wide, linear, subobtuse, falcate; posterior lobe $c a 7 \mathrm{~mm}$ long,
$1.5 \mathrm{~mm}$ wide, linear-lanceolate, obtuse, subfalcate. Lateral sepals ca $9 \mathrm{~mm}$ long, $2.5 \mathrm{~mm}$ wide, obliquely ovate-lanceolate, acute. Lip 3-lobed nearly at base; middle lobe ca $8 \mathrm{~mm}$ long, $0.9 \mathrm{~mm}$ wide, linear, obtuse; lateral lobes 7.0-7.5 mm long, $1.3 \mathrm{~mm}$ wide, obliquely linearoblanceolate, acute, diverging. Spur ca $25 \mathrm{~mm}$ long, filiform, distinctly swollen in apical third and there $2.5 \mathrm{~mm}$ in diameter, acute. Gynostemium short, massive. Antherophores short, joined to equal rostellophores. Pollinia longer than filiform caudiculae. Stigmaphores slightly longer than antherophores and rostellophores. Rostellum medium lobe triangular-subulate, massive, exceeding the anther, placed in front of the connective. Rostellophores crescentiform. Viscidia 2, rather massive.

Notes. This species resembles Rhinorchis macilenta (Lindley) Szlach., from which it differs by having anterior petals lobes shorter than
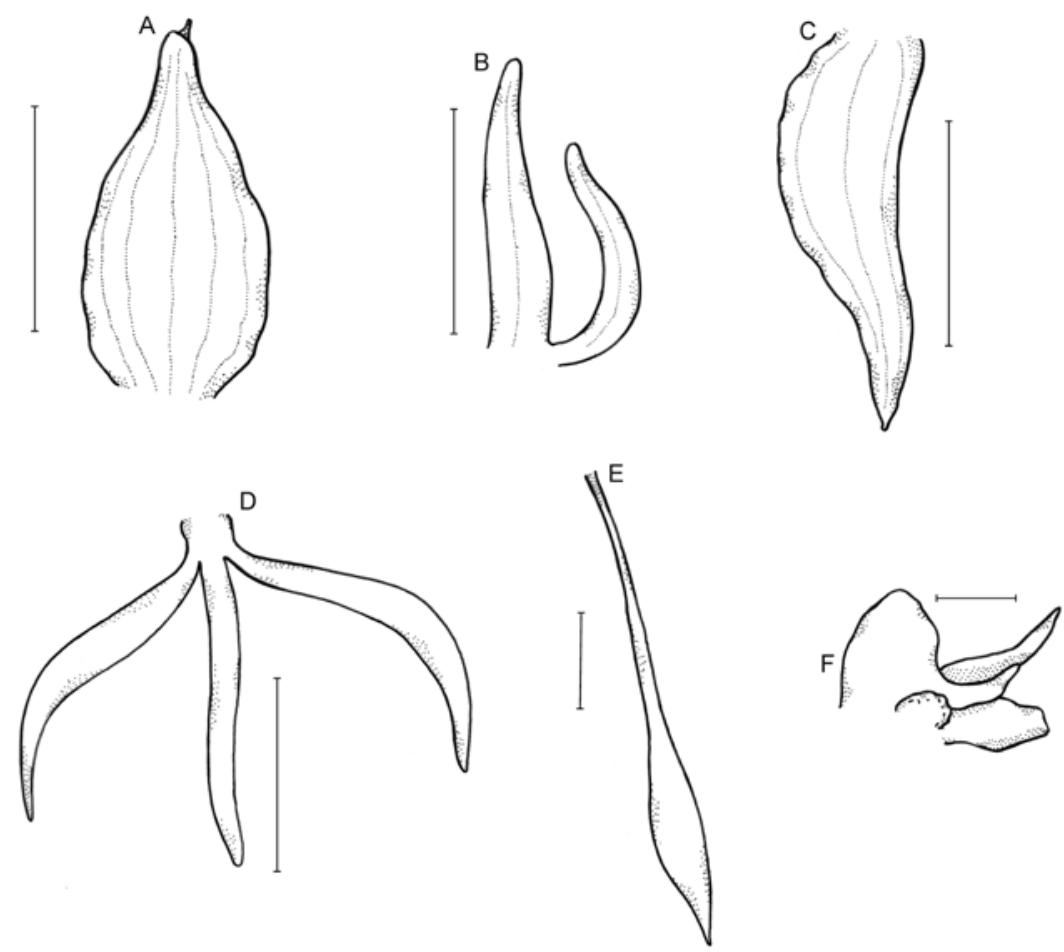

Fig. 1. Rhinorchis heteroplectron Rchb. f. ex Szlach. \& Kolan., sp. nov. - dissected perianth. A - dorsal sepal, B - petal, C - lateral sepal, D - lip, E - spur, F - gynostemium (drawn by Michał Lamczyk from holotype). Scale bars: A-E = $5 \mathrm{~mm}, \mathrm{~F}=1 \mathrm{~mm}$. 
the posterior lobes (vs lobes subequal in length) and strongly falcate and filiform, and an acute spur (vs spur cylindrical, blunt). Another similar species is R. leaoana (Schltr.) Szlach., but unlike in $R$. heteroplectron its lip lateral lobes are filiform, longer than the middle one, and the spur is bifid at the apex. In $R$. heteroplectron the lip lateral lobes are linear-oblanceolate, shorter than the middle one, and the spur is acute. From R. trifida (Humb., Bonpl. \& Kunth) Szlach., widely distributed in the Neotropics, the new species differs by its spur form, which is narrowly cylindrical, clavate at the bifid apex, and reaching $30-120 \mathrm{~mm}$ in length.

\section{KeY tO RHINORCHIS SPECIES FROM FRENCH GUIANA}

1. Anterior petal lobe shorter than posterior one ... 2

1 . Both petal lobes equal or subequal in length ... 3

2. Lip middle lobe slightly longer than lateral lobes . . R. heteroplectron Rchb. f. ex Szlach. \& Kolan.

$2^{*}$. Lip middle lobe much shorter than lateral lobes R. dusenii (Schltr.) Szlach.

3. Pedicel and ovary ca $10 \mathrm{~cm}$ long, spur $30-110 \mathrm{~mm}$ long .......... R. pauciflora (Lindl.) Szlach. 3. Pedicel and ovary up to $5.5 \mathrm{~cm}$ long, spur up to $30 \mathrm{~mm}$ long .................. 4 4. Spur bifid at apex ... R. trifida (Kunth) Szlach. 4. Spur shortly acuminate at apex ........... R. macilenta (Lind1.) Szlach.
ACKNOWLEDGEMENTs. We thank the Curator and staff of $\mathrm{W}$ for their kind hospitality and assistance during visits, the anonymous reviewers for helpful remarks on the manuscript, and Michał Lamczyk for preparing the illustration. The research described here was supported by the Polish Ministry of Science and Higher Education (grant no. 8124/B/PO1/2011/40).

\section{REFERENCES}

McNeill J., Barrie F. R., Buck W. R., Demoulin V., Greuter W., Hawksworth D. L., Herendeen P. S., Knapp S., Marhold K., Prado J., Prud'homme van Reine W. F., Smith G. F., Weirsema J. H. \& Turland N. J. 2012. International Code of Nomenclature for algae, fungi, and plants (Melbourne Code). Regnum Veg. 154: [i]-xxx, 1-208.

RAFINESQUe C. S. 1837. Flora telluriana, pars secunda. H. Probasco, Philadelphia.

SzlachetKo D. L. 1995. Systema orchidalium. Fragm. Florist. Geobot., Suppl. 3: 1-152.

SzlachetKo D. L. 2004a. Materiaux pour la révision des Habenariinae (Orchidaceae, Orchidoideae) 5. Richardiana 4: 103-108.

Szlachetko D. L. 2004b. Materiaux pour la révision des Habenariinae (Orchidaceae, Orchidoideae) 4. Richardiana 4: 52-65.

SzlachetKo D. L. 2012. Rhinorchis (Orchidaceae, Orchidoideae), a new neotropical genus highlighted from Habenaria. Richardiana 13: 71-79.

SzlachetKo D. L. \& Kras M. 2006. Notes sur le genre Habenella. Richardiana 6: 33-39.

Received 4 December 2013 